\title{
MORPHOGENESIS OF THE GAMETOPHYTES OF EIGHT MEXICAN SPECIES OF BLECHNUM (BLECHNACEAE)
}

\author{
Aniceto Mendoza-Ruiz and Blanca Pérez-García \\ Universidad Autónoma Metropolitana-Iztapalapa, Área de Botánica Estructural y \\ Sistemática Vegetal, Departamento de Biología, Apdo. postal 55-535, \\ 09340 México, D.F. México amr@xanum.uam.mx
}

\begin{abstract}
A comparative study of the gametophytes of eight Mexican species of the genus Blechnum (Blechnaceae) is described. Fertile plants for spore collection were obtained at different Mexican localities. The spores were sown in agar enriched with Thompson media and cultured at $22-25^{\circ} \mathrm{C}$, with a light regime of 12 hours. Spores of all species are monolete, ellipsoidal to spheroidal, and non-chlorophyllous. Vittaria-type germination occurred after 6-14 days followed by a 2-6-cell-long filament and Aspidium-type prothallial development. Adult gametophytes are cordiform-spatulate to cordiform-reniform and have wide wings with numerous unicellular marginal and superficial hairs. Sporophytes developed only in $B$. occidentale and B. polypodioides.
\end{abstract}

Key words: Blechnaceae, Blechnum, fern, gametophytes, Mexico, morphogenesis.

\section{RESUMEN}

Se describe el estudio comparativo de la fase sexual de ocho especies del género Blechnum para México. Las plantas fértiles para la obtención de las esporas fueron recolectadas en distintas localidades del país. Éstas se sembraron en agar enriquecido con medio nutritivo de Thompson y se pusieron a germinar temperatura de $22-25{ }^{\circ} \mathrm{C}$ y con un régimen lumínico de $12 \mathrm{~h}$ luz. Las esporas de todas las especies son monoletes, elipsoidales a esferoidales, no clorofílicas; presentan germinación tipo-Vittaria, filamento de 2-6 células de longitud, desarrollo protálico tipo-Aspidium. Los gametofitos adultos son cordiforme-espatulados a cordiforme-reniformes, presentan amplias alas con numerosos pelos unicelulares marginales y superficiales; los gametangios son del tipo de los helechos leptosporangiados. Los esporofitos sólo se formaron en B. occidentale y B. polypodioides. 
Palabras clave: Blechnaceae, Blechnum, gametofitos, helecho, México, morfogénesis.

\section{INTRODUCTION}

Blechnum L. is the largest genus of the family Blechnaceae (Pteridophyta). The nearly 200 species are primarily tropical. There are 15 species of Blechnum in Mexico. Mexican species are terrestrial, hemiepiphytic or epiphytic and most are widespread, extending into Central and South America. The genus has sometimes been divided on the basis of monomorphic (Blechnum) vs. dimorphic fronds (Lomaria Willd.), but there are several further groupings of dimorphic-fronded species, each of which could conceivably be considered a distinct genus (Smith, 1981; Mickel \& Beitel, 1988; Moran, 1995; Mickel \& Smith, 2004).

Gametophyte morphology of several species of Blechnum has already been studied, mostly in Old World species such as B. gibbum (Lab.) Mett., B. orientale L. and B. spicant (L.) Wither (Stübner, 1882; Lampa, 1901; Döpp, 1927; Karpowicz, 1927; Stokey, 1951; Stokey \& Atkinson, 1952a, 1952b; Kachroo, 1955; Stone, 1961; Nayar, 1962; Nayar, et al., 1966; Beisvag, 1970; Cousens, 1979, 1981; Chiou, 1989; Fernández et al., 1997; Menéndez et al., 2006a, 2006b), but it is scarcely known for the American species, with the exception of some from South America, mainly Chile and Argentina (Rodríguez-Ríos, 1973; Durán \& de la Sota, 1996; Pérez-García et al., 1996).

Considering the morphological differences that exist in the Blechnum sporophyte, it is necessary to continue studies on the development of the gametophytic phase, in order to determine whether there are features that allow to recognize groups on infrageneric level.

This paper describes the gametophytic morphogenesis of Blechnum appendiculatum Willd., B. falciforme (Liebm.) C. Chr., B. gracile Kaulf., B. occidentale L., B. polypodioides Raddi, B. schiedeanum (Schltdl. ex C. Presl) Hieron., B. serrulatum Rich. and B. $\times$ caudatum Cav. All species are native to Mexico.

\section{MATERIALS AND METHODS}

Spores were obtained from numerous locations in Mexico (Table 1). Fertile pinnae with mature sporangia were stored inside paper envelopes and left to dry in 
Table 1. Sites of origin of the taxa under research.

\begin{tabular}{|c|c|c|c|}
\hline Taxa & Vouchers & State/Municipality/Locality & $\begin{array}{l}\text { Vegetation/ } \\
\text { altitude }\end{array}$ \\
\hline \multirow{2}{*}{$\begin{array}{l}\text { Blechnum } \\
\text { appendiculatum } \\
\text { Willd. }\end{array}$} & AMR-600 & $\begin{array}{l}\text { - Oaxaca, San Gabriel Mixtepec, ca. } 4 \\
\text { km after San Juan Lachao Nuevo. }\end{array}$ & MRF, $1068 \mathrm{~m}$ \\
\hline & AMR-628a & $\begin{array}{l}\text { - Veracruz, Fortín de las Flores, ca. } 3 \\
\text { km after Fortín, towards Orizaba. }\end{array}$ & OFC, $960 \mathrm{~m}$ \\
\hline $\begin{array}{l}\text { B. falciforme } \\
\text { (Liebm.) C. Chr. }\end{array}$ & AMR-782 & $\begin{array}{l}\text { - Oaxaca, Totontepec Villa de } \\
\text { Morelos, } 3 \text { km after Totontepec } \\
\text { towards Santa María Yocochii. }\end{array}$ & MMF, $2064 \mathrm{~m}$ \\
\hline B. gracile Kaulf. & AMR-851 & $\begin{array}{l}\text { - Veracruz, San Andrés Tuxtla, Lote } \\
69 \text { in the Los Tuxtlas Biology Station, } \\
\text { UNAM, near Laguna Azul. }\end{array}$ & MEF, $150 \mathrm{~m}$ \\
\hline \multirow[t]{2}{*}{ B. occidentale L. } & AMR-609 & $\begin{array}{l}\text { - Veracruz, Catemaco, ca. } 1 \text { km before } \\
\text { Tebanca, towards San Pedro Soteapan. }\end{array}$ & MRF, $360 \mathrm{~m}$ \\
\hline & AMR-614 & $\begin{array}{l}\text { - Veracruz, Catemaco, ca. } 3 \text { km after } \\
\text { Coyame towards Adolfo López } \\
\text { Mateos. }\end{array}$ & MEF, $650 \mathrm{~m}$ \\
\hline \multirow[t]{2}{*}{$\begin{array}{l}\text { B. polypodioides } \\
\text { Raddi }\end{array}$} & AMR-604 & $\begin{array}{l}\text { - Oaxaca, San Pedro el Alto, } 3.5 \text { km } \\
\text { before Santa María Jalatengo and } \\
4 \text { km after La Soledad, Pochutla- } \\
\text { Miahuatlán road. }\end{array}$ & OPF, $1548 \mathrm{~m}$ \\
\hline & AMR-855 & $\begin{array}{l}\text { - Oaxaca, Ayotzintepec, towards La } \\
\text { Nueva Esperanza, } 9 \text { km after Valle } \\
\text { Nacional towards La Esperanza. }\end{array}$ & MMF, $570 \mathrm{~m}$ \\
\hline $\begin{array}{l}\text { B. schiedeanum } \\
\text { (Schltdl. ex C. } \\
\text { Presl) Hieron. }\end{array}$ & AMR-716 & $\begin{array}{l}\text { - Veracruz, Juchique de Ferrer, ca. } 1 \\
\text { km after Santa Rita, towards Misantla. }\end{array}$ & MMF, $1410 \mathrm{~m}$ \\
\hline B. serrulatum Rich. & AMR-896 & $\begin{array}{l}\text { - Veracruz, Coatzacoalcos. } 7 \mathrm{~km} \\
\text { before Coatzacoalcos, on the federal } \\
\text { road Minatitlán-Coatzacoalcos. }\end{array}$ & $\mathrm{SV}, 0 \mathrm{~m}$ \\
\hline B. xcaudatum Cav. & AMR-627 & $\begin{array}{l}\text { - Veracruz, Fortín de las Flores, ca. } 3 \\
\text { km after Fortín towards Orizaba. }\end{array}$ & OFC, $960 \mathrm{~m}$ \\
\hline
\end{tabular}

AMR, Aniceto Mendoza Ruiz; OFC, oak forest with coffee plants; OPF, oak pine forest; MMF, mesophilous mountain forest; MEF, moist evergreen forest; MRF, montane rainforest; SV, swamp vegetation. 
laboratory conditions to facilitate spore release. After several days, the contents of the envelopes were sifted with a metallic mesh with openings $0.074 \mathrm{~mm}$ in diameter to eliminate the remains of sporangia and indusia. Spores of all species were sown in Petri dishes $5 \mathrm{~cm}$ in diameter (20 dishes for each species, with three replicates for each species) containing previously sterilized agar with Thompson's nutrients (Klekowski, 1969; Mendoza-Ruiz \& Pérez-García, 2005). The spores were spread on the surface of the solidified medium with a thin brush, with an average density of $100-150$ spores $/ \mathrm{cm}^{2}$.

The Petri dishes were maintained in transparent plastic bags to avoid dehydration and contamination under a $12 \mathrm{~h}$ light/darkness photoperiod (with 75 watts “day-light” lamps) at $22-25{ }^{\circ} \mathrm{C}$ temperature. Each dish was initially opened every third day in order to determine when germination began and to observe the different developmental stages of the gametophyte, as well as to dampen the growth media with sterilized distilled water and enable sperm to move once the gametophytes became sexually mature. To investigate light requirements for germination and development, two dishes of each species were kept in darkness and opened 100 days after they had been sown. Spore sizes were also measured from material in water, using a compound microscope equipped with an ocular micrometer. For the average size of spores, thirty spores were measured for each species (Erdtman \& Sorsa, 1971).

Photomicrographs were taken of live material through a stereoscopic microscope and optic microscope, with black and white, $35 \mathrm{~mm}$, TIMAX-100 film an OLYMPUS BX41 microscope, with Digital Camera Olympus C-5060 wide zoom.

\section{RESULTS}

The spores of all studied species were monolete, ellipsoidal to spheroidal, light to dark brown or yellow, and achlorophyllous. The perispore was smooth, with small papillae, or reticulate. Spore size varied within the following ranges for each species: Blechnum appendiculatum, 37(41)49 $\mu \mathrm{m}$ long x 24(27)31 $\mu \mathrm{m}$ wide (Fig. 1); B. falciforme, 53(57)68 x 37(40)49 $\mu \mathrm{m}$; B. gracile, 41(43) 47 x 27(29)31 $\mu \mathrm{m}$ (Fig. 2); B. occidentale, 34(37)40 x 22(24)26 $\mu \mathrm{m}$ (Fig. 3); B. polypodioides, 37(40)43 x 23(25)28 $\mu \mathrm{m}$; B. schiedeanum, 64(67)74 x 44(49)54 $\mu \mathrm{m}$; B. serrulatum, 34(38)40 x 25(28)39 $\mu \mathrm{m}$; and B. $\times$ caudatum, 37(45)54 x 25(28)32 $\mu \mathrm{m}$.

Spores of Blechnum gracile, B. occidentale, B. polypodioides, B. serrulatum, and $B$. $\times$ caudatum germinated from day 6 , whereas those of $B$. falciforme and $B$. 

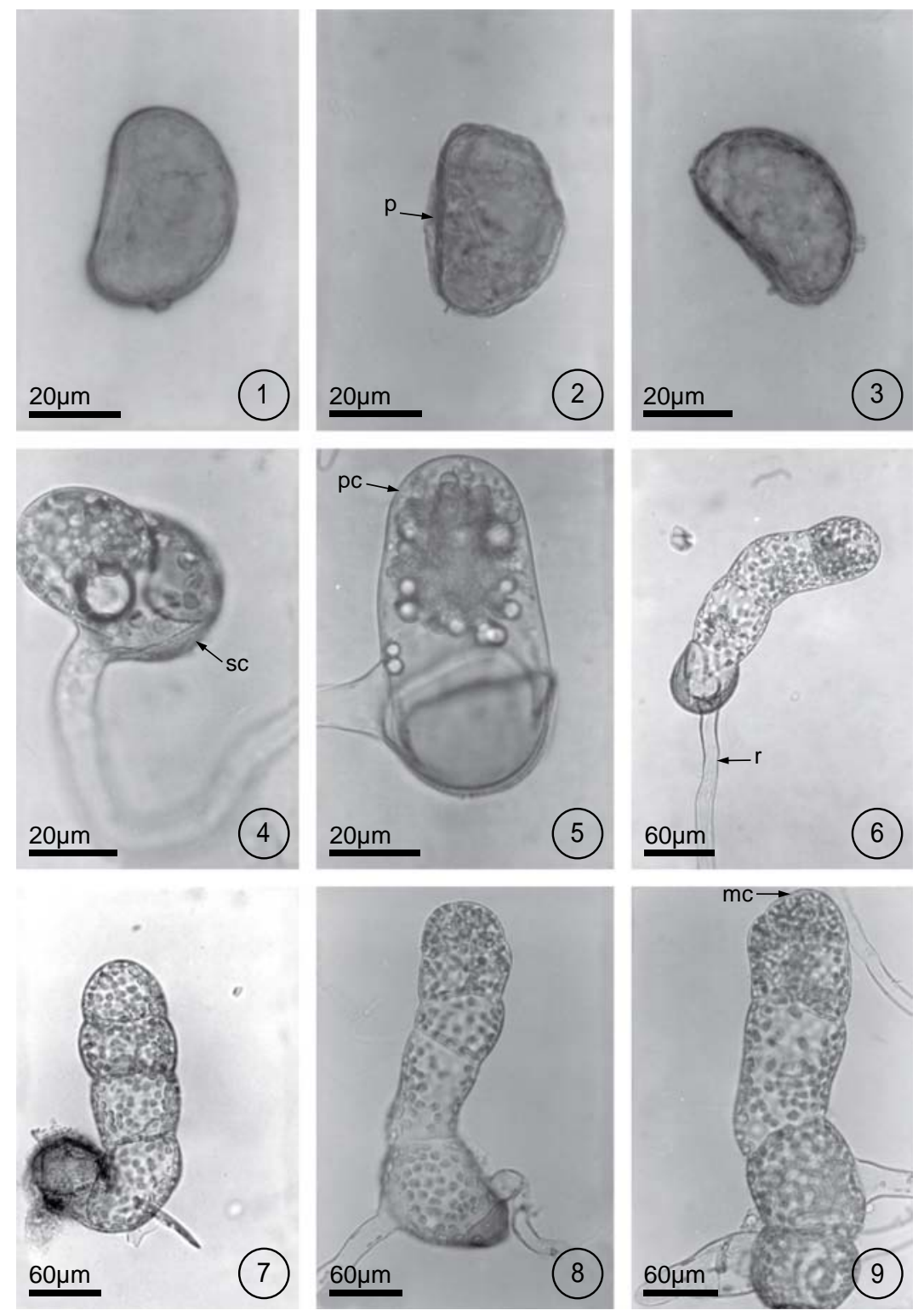

Figs. 1-9. Spores and filamentous phase of Blechnum. Figs. 1-3. Blechnum spores: 1. B. appendiculatum, 2. B. gracile, 3. B. occidentale; Fig. 4. germination. B. occidentale (8 days); Figs. 5-9. filamentous phase: 5 and 8. B. occidentale (9-11 days), 6 and 9. B. polypodioides (9 days), 7. B. falciforme (14 days). mc $=$ meristematic cell, $\mathrm{p}=$ perispore, $\mathrm{pc}=$ prothallial cell, $\mathrm{sc}=$ spore cover, $\mathrm{r}=$ rhizoid. 
schiedeanum germinated on day 14. All had Vittaria-type germination according to the criteria of Nayar \& Kaur (1971). The first cellular division produced the hyaline rhizoidal cell, perpendicular to the polar axis of the spore. Subsequently, the prothallial cell, which was short and with abundant chloroplasts, emerged from the spores cover (Fig. 4). Because spores kept in the dark did not germinate after 100 days, they are considered positively photoblastic.

The prothallial cell underwent periclinal divisions giving rise to 2-6-cell-long uniseriate filaments. This was a short phase that began on day 10 and lasted until day 20 (Figs. 5-9). Once the filament was differentiated, a two-dimensional thallus developed in two ways: 1) from the apical cell of the filament which divided crosswise forming two unequal cells whose function is to form a meristematic cell that will initiate the development of the plate, or 2) through the lengthwise division of the intercalary cells of the filament that gave place to the plate phase and, later, to the establishment of a pluricellular meristem (Figs. 9-11). These two developmental types are present in some species of Blechnum.

Plate phase formation began between days 20-40 with an orientation change in the division plane of the apical cell, showing a variation in the prothallial development pattern. In Blechnum gracile, B. occidentale, B. polypodioides, B. serrulatum, and $B . \times$ caudatum, the apical cell of the filament divided crosswise to form two unequal cells whose function was to form a meristematic cell from which the plate phase will later develop (Fig. 10). However, in B. falciforme and B. schiedeanum the plate phase began with the lengthwise division of the filament's intercalary cells to form the plate and the subsequent establishment of a pluricellular meristem, which then formed the gametophytes (Figs. 11-15). Gametophyte development in all species corresponded to the Aspidium-type, according to Nayar \& Kaur (1969). During this stage, the gametophytes were vegetative. Rhizoids were few in number, light brown, and longer than the gametophyte (Figs. 13-17). It is during this stage that the development of marginal unicellular hairs began in all the studied species (Figs. 11-12).

All species were unisexual and gametangia (initially archegonia) differentiated between day 50 and day 80 . Archegoniate individuals were the first to develop (protogynous) within a population and did so within an asynchronous manner. In Blechnum falciforme, archegonia were apparent by day 40; in B. gracile, $B$. polypodioides, and $B$. schiedeanum, by day 50 ; in $B$. occidentale, $B$. serrulatum, and $B$. $\times$ caudatum by day 60 ; and in $B$. appendiculatum by day 70 . Female gametophytes were spatulate-cordiform to cordiform-reniform and the wings broad. The cushion became well differentiated between day 70 and 100 (Figs. 21-22) 

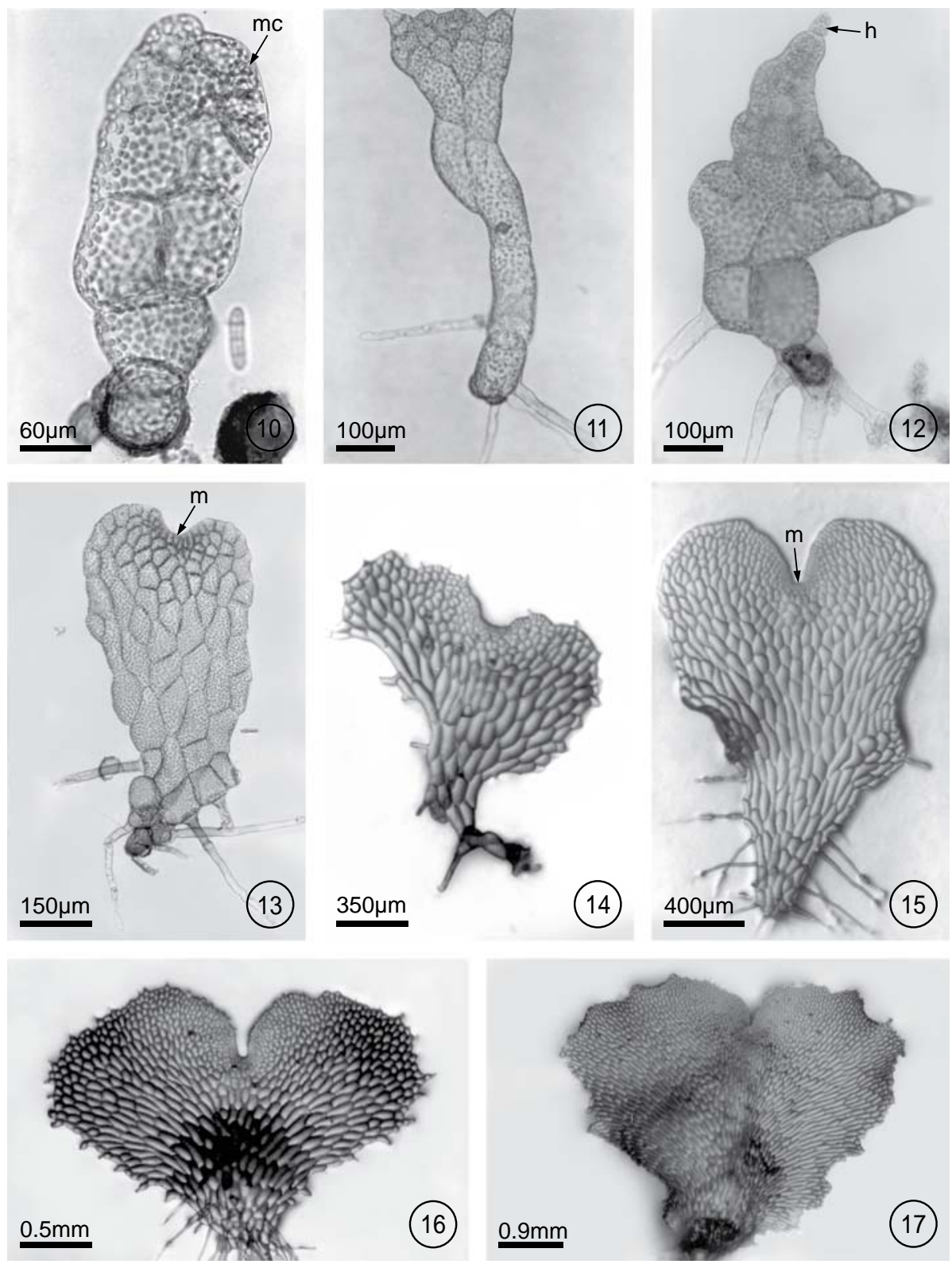

Figs. 10-17. Development of plate phase and young plate gametophytes of Blechnum: 10 . B. falciforme (14 days), 11. B. occidentale (22 days), 12. B. serrulatum (11 days), 13 . B. falciforme (28 days), 14. B. gracile (30 days), 15. B. falciforme (47 days), 16. B. polypodioides (41days), 17. $B$. gracile (50 days). $\mathrm{m}=$ meristem, $\mathrm{mc}=$ meristematic cell, $\mathrm{h}=$ hairs. 

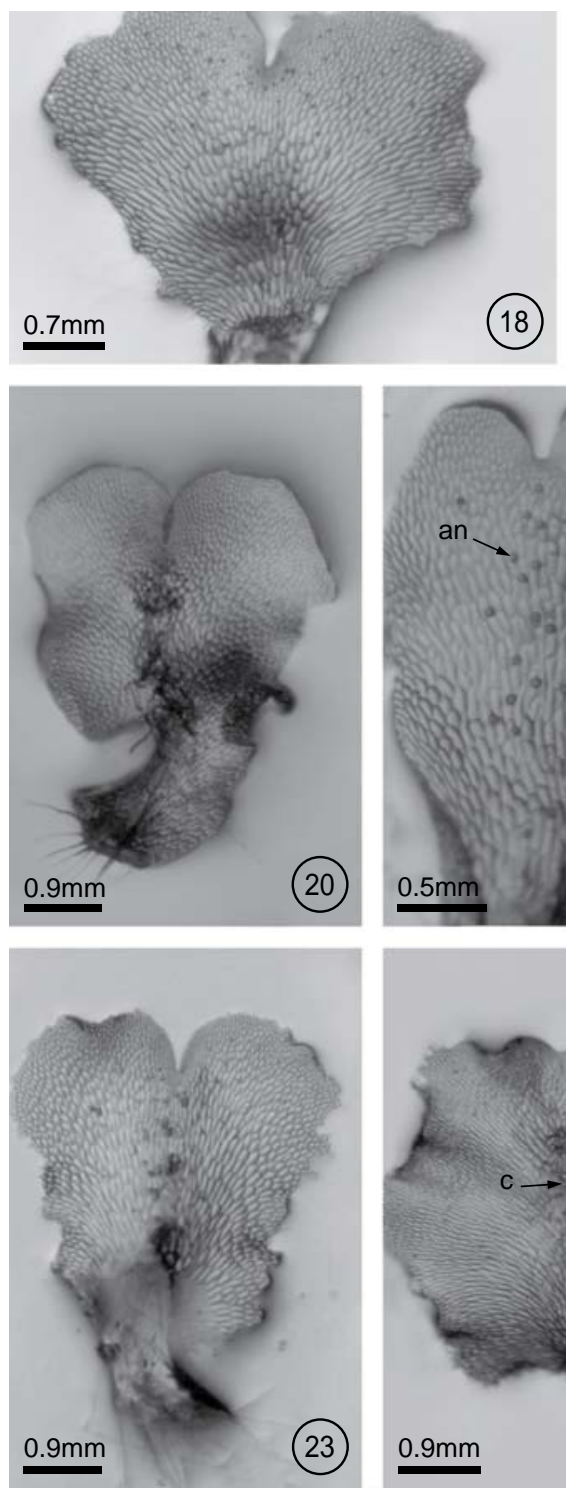
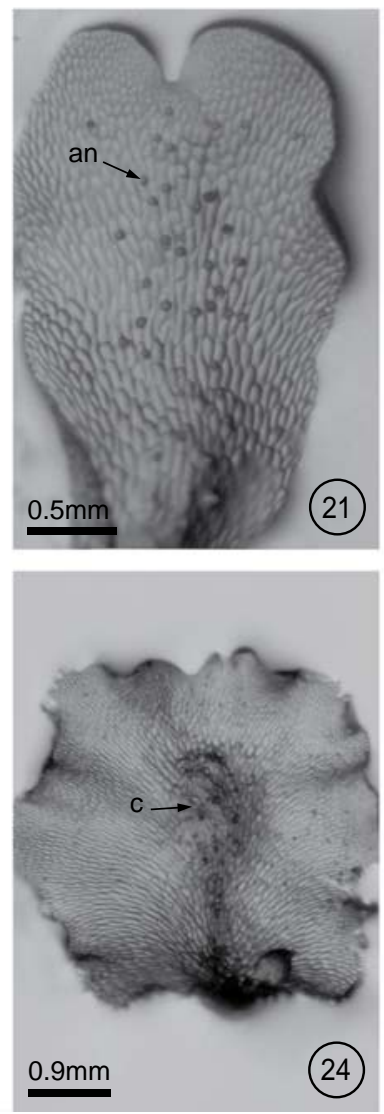
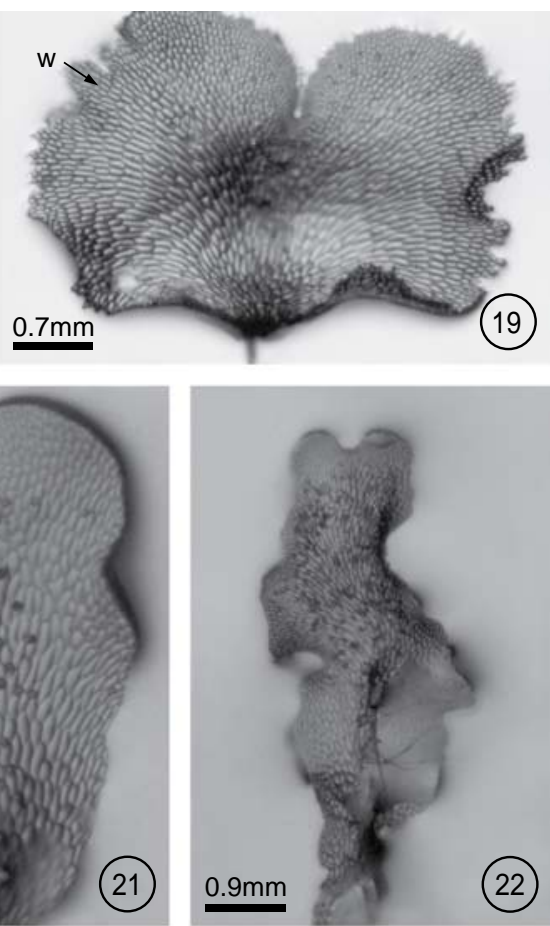

(22)

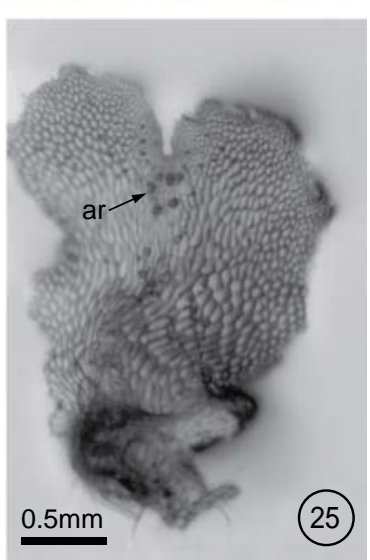

Figs. 18-25. Adult gametophytes of Blechnum: 18. vegetative gametophyte of B. gracile (50 days), 19. vegetative gametophytes of $B$. $\times$ caudatum (69 days), 20. gametophyte with archegonia of $B$. falciforme (118 days), 21-22. gametophytes with antheridia of $B$. falciforme (80 and 118 days), 23. B. schiedeanum's female gametophyte (100 days), 2425. B. apendiculatum's gametophytes with archegonia (50-100 days). an $=$ antheridia, $a r=$ archegonia, $\mathrm{c}=$ cushion, $\mathrm{w}=$ wings. 
with numerous unicellular capitate hairs in the gametophyte margin and, in lesser amounts, on both surfaces (Figs. 26-27). The archegonia were distributed on the cushion near the meristematic zone (Figs. 20, 23-25, 28, 30, 31). Their necks were elongated, 4-5 cells long, and slightly curved towards the basal region of the gametophyte. The mouth was composed of 4 cells, and the necks of four rows 3-5 cells long (Fig. 32).

The antheridia developed after the archegonia, between day 60 and day 70 in most species, with the exception of Blechnum appendiculatum in which they developed after day 80 (Figs. 21-22). Male gametophytes were spatulateelongated to spatulate-cordiform, their cushion scarcely differentiated between 60-80 days, and their wings were narrower than those of females (Figs. 18-25). Antheridia were oblong, sometimes with a slightly narrowed base, and composed of a basal cell, an annular or ring cell, and a very conspicuous opercular cell (Fig. 33). They were distributed irregularly on the on the ventral face of spatulate gametophytes.

Sporophytes developed in Blechnum occidentale and B. polypodioides 90 days after the spores had been sown. The first leaves were spatulate to bilobate with open dichotomous venation (Fig. 34). The petiole was long and terete with hyaline, capitate hairs. Stomata were found only on the abaxial side of the blade and lacked subsidiary cells.

\section{DISCUSSION}

The species studied here can be placed in two groups based on spore size and frond morphology. The first contains species with monomorphic leaves, such as Blechnum appendiculatum, B. gracile, B. occidentale, B. polypodioides, B. serrulatum and $B$. $\times$ caudatum, which have small spores measuring on average 37 to $43 \mu \mathrm{m}$ long by 24 to $31 \mu \mathrm{m}$ wide. The second group contains B. falciforme and B. schiedeanum, which have dimorphic leaves and larger spores measuring on average 57 to $67 \mu \mathrm{m}$ long by 40 to $49 \mu \mathrm{m}$ wide. Duration of the pre-germination phase following exposure to agar based media corresponded with spore size, with smaller spore species germinating earlier than species with the two largest spores (i.e., B. falciforme and B. schiedeanum).

The Aspidium-type differs from all others in that there is often a margin of variability in the process of development and that it is conditioned by early hair formation in the young gametophyte. 

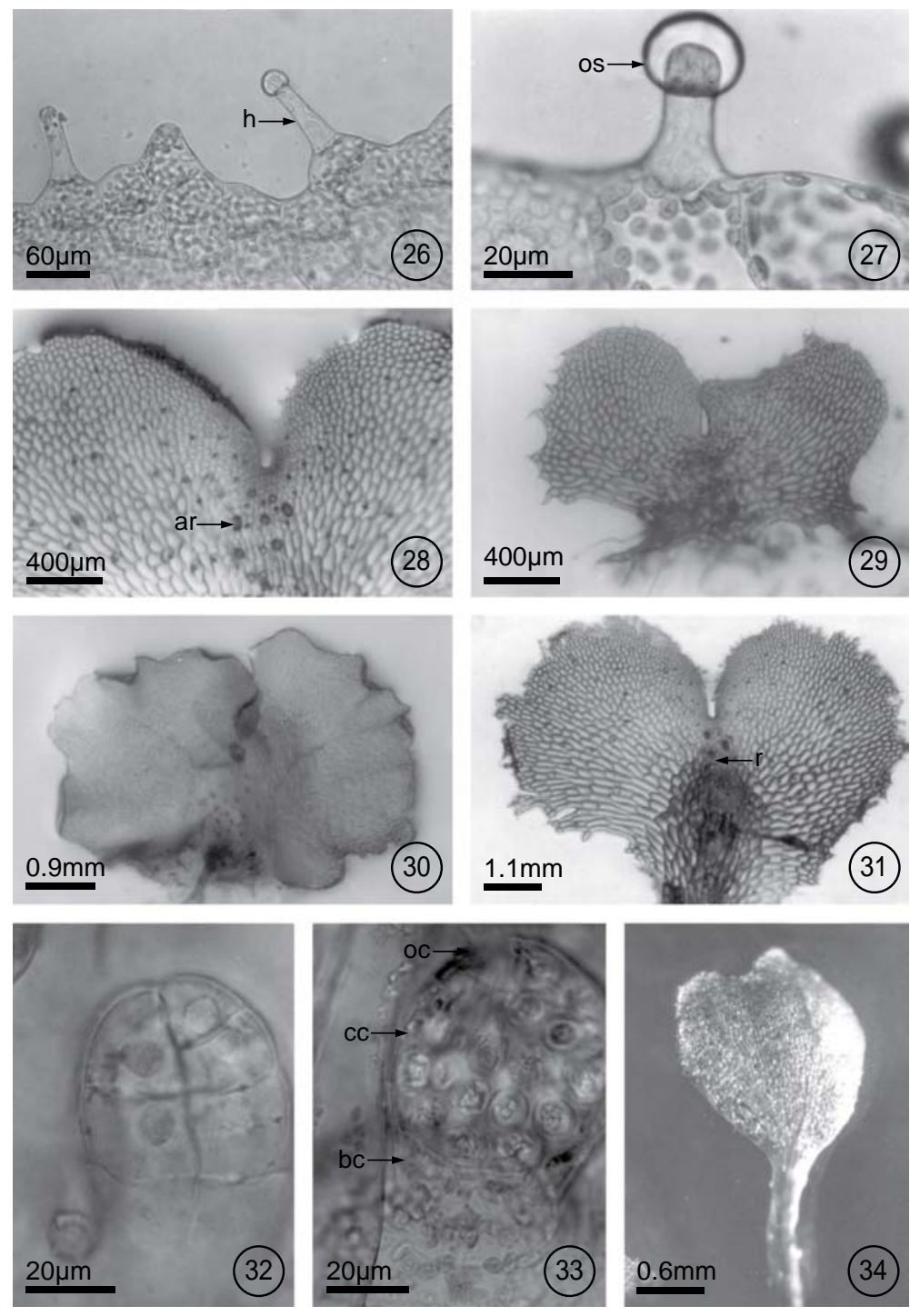

Figs. 26-34. Blechnum's adult gametophytes, hairs, gametangia and sporophytes: 26. B. apendiculatum's marginal hairs (100 days), 27. B. gracile's hairs with secretion (70 days), 28. B. gracile's meristematic zone with archegonia (52 days), 29-30. B. serrulatum's female gametophytes (43 and 52 days); 31. B.×caudatum's female gametophyte (170 days), 32-33. neck of archegonium and antheridium of B. polypodioides (55 days), 34. B. polypodioides sporophyte's first leaf (100 days). bc = basal cell, $\mathrm{cc}=$ annular cell, oc $=$ opercular cell, os $=$ oil secretion, ar = archegonia. 
The Aspidium-type of development is a constant characteristic except in some Australian and Chilean species as Blechnum nudum Mett., B. penna-marina (Poir.) Kuhn and $B$. chilense (Kaulf.) Mett., which lack hairs during the entire developmental stage and therefore have the Adiantum-type of gametophyte development.

In the Adiantum-type, the terminal cell of the germ filament divides by a wall oblique to the long axis of the filament, and this is followed by another division by a wall at right angles to it. Thus, a transverse row of three daughter cells is formed, of which the middle one is wedge-shaped and acts as a meristematic cell (Nayar, 1962; Nayar \& Kaur, 1971; Rodríguez-Ríos, 1973; Durán \& de la Sota, 1996; Pérez-García et al., 1996).

Hair abundance varies among species and depends on the stage of prothallial development. In some species, such as Blechnum cycadifolium (Colla) Sturm., B. orientale L., and B. gibbum (Lab.) Mett., young prothallia are glabrous, with the hairs developing only when they are mature. In other species such as B. buchtienii Rosenst., B. brasiliense Desv. and B. spicant (L.) Roth, gametophytes develop hairs soon after attaining a plate phase as is the case for the species studied here (Atkinson, 1973). On the other hand, gametophytes of the Australian species B. nudum and $B$. penna-marina, and the Chilean species $B$. chilense, are completely glabrous during their entire development (Stokey \& Atkinson, 1952a, 1952b; Stone, 1961; Pérez-García et al., 1996).

Although Blechnum is often considered to be a big genus, it is relatively homogeneous for such a large group. Morphological differences in the sporophytes such as monomorphic and dimorphic fronds and size of spores, seemingly share a similar pattern of germination and development prothallial, and gametophytes of Blechnum are not sufficiently known to provide information for an adequate infrageneric classification (Table 2). Study of the whole genus, especially the gametophytes, will be necessary to provide data for establishing relationships within the section, fronds dimorphic groups or fronds monomorphic groups (Smith, 1981, Tryon \& Tryon, 1982; Mickel \& Beitel, 1988; Mickel \& Smith, 2004).

\section{ACKNOWLEDGMENTS}

We wish to thank to Victor Steinmann, Jacqueline Ceja, Gary K. Greer, and all our reviewers for the comments and suggestions made to the manuscript, and to Jorge Lodigiani for printing the photographic material. 
Acta Botanica Mexicana 88: 59-72 (2009)
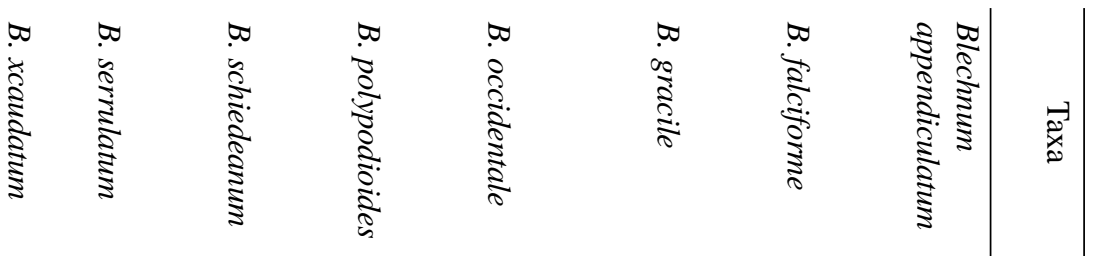

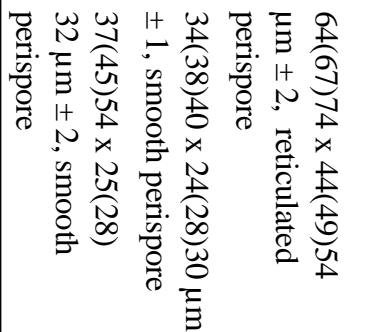
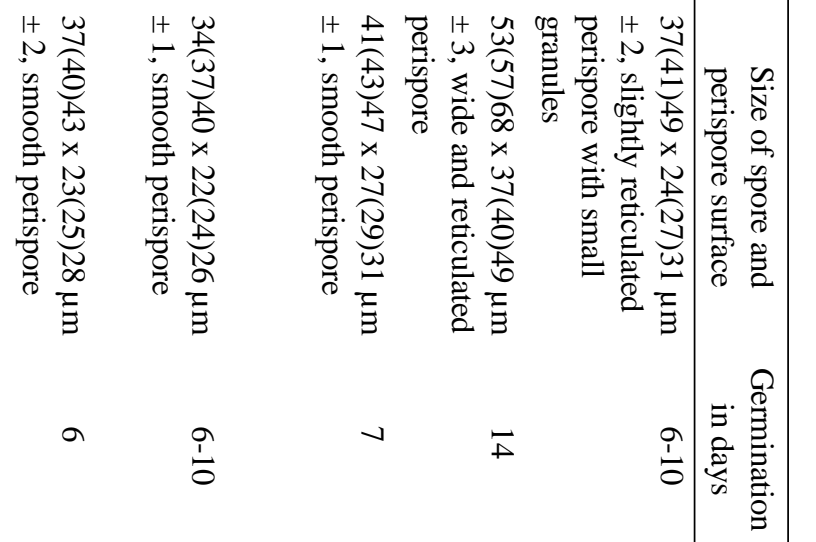

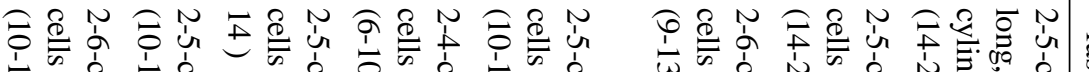

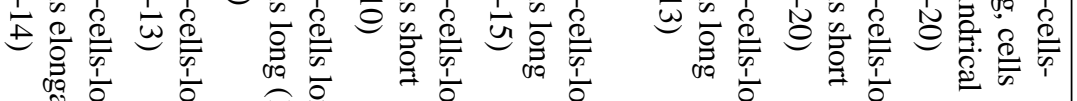
兽. 岕 兽 空 泀 密 疍. 突 寻亦

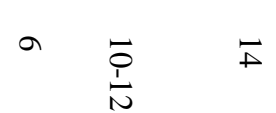

a $\quad \stackrel{0}{0}$

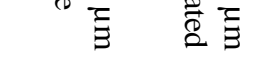

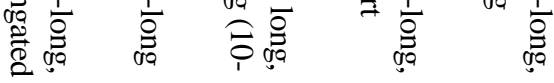

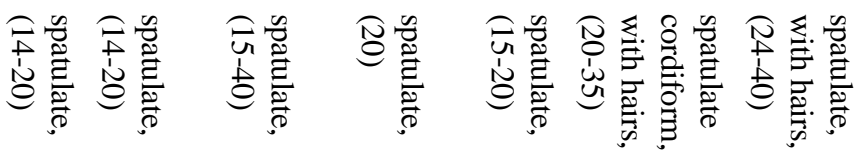
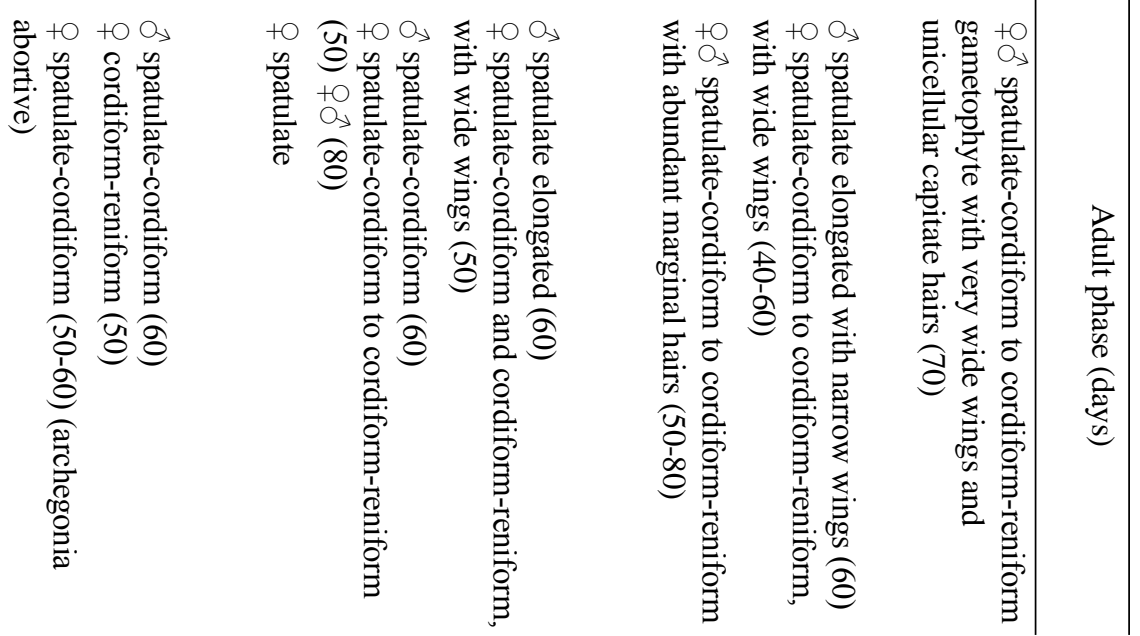

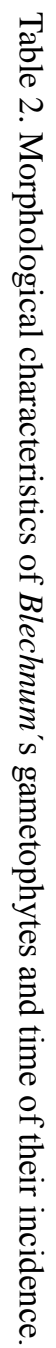




\section{LITERATURE CITED}

Atkinson, L. R. 1973. The gametophytes and family relationships. In: Jermy, A. C., J. A. Crabbe \& B. A. Thomas (eds.). The phylogeny and classification of the ferns. Bot. J. Linn. Soc. 67(Suppl. 1): 73-90.

Beisvâg, T. 1970. An electron microscopic investigation of the young gametophyte of Blechnum spicant (L.) Roth. Grana Palynol. 10: 121-135.

Chiou, W. I. 1989. The gametophytes and juvenile sporophytes of Blechnum orientale L. Yushania 6: 1-8.

Cousens, M. I. 1979. Gametophyte ontogeny, sex expression, and genetic load as measures of population divergence in Blechnum spicant. Amer. J. Bot. 66: 116-32.

Cousens, M. I. 1981. Blechnum spicant: habitat and vigor of optimal, marginal and disjunct populations, and field observations of gametophytes. Bot. Gaz. (Crawfordsville) 142: 251-258.

Döpp, W. 1927. Untersuchungen über die Entwicklung von Prothallien einheimischer Polypodiaceen. Pflanzenforschung 8: 1-58.

Durán, M. L. \& E. R. de la Sota. 1996. Delayed sex expression of hybrid gametophytes in Blechnum. In: Gibby, J. M. \& R. J. Johns (eds.). Pteridology in perspective. Royal Botanical Gardens. Kew. p. 515.

Erdtman, G. \& P. Sorsa. 1971. Pollen and spore morphology/plant taxonomy. Pteridophyta. Almqvist \& Wiksell. Stockholm. 302 pp.

Fernández, H., A. M. Bertrand \& R. Sánchez-Tamés. 1997. Gametophyte culture and antheridiogen activity in Blechnum spicant L. Plant Cell Tissue Org. Cult. 50: 71-74.

Kachroo, P. 1955. Gametophytes of Blechnum orientale L. and Blechnum spp. Sci. \& Cult. 20: 402-403.

Karpowicz, W. 1927. Studien über die Entwicklung der Prothallien und der ersten Sporophyllblätter der einheimischer Farnkräuter (Polypodiaceae). Bull. Int. Acad. Polon. Sci. Lettr. Sér. B 1: 1-26.

Klekowski, E. J., Jr. 1969. Reproductive biology of the pteridophyta. III. A study of the Blechnaceae. J. Linn. Soc. Bot. 62: 361-377.

Lampa, E. 1901. Über die Entwicklung einiger Farnprothallien. S. B. Akad. Wiss. Wien 110: 95-111.

Mendoza-Ruiz, A. \& B. Pérez-García. 2005. Análisis comparativo de la fase sexual de dos especies de Microgramma (Polypodiaceae, Pleopeltoideae). Acta Bot. Mex. 71: $1-10$.

Menéndez, V., A. M. Revilla \& H. Fernández. 2006a. Growth and gender in the gametophyte of Blechnum spicant L. Plant Cell Tissue Org. Cult. 86: 47-53.

Menéndez, V., A. M. Revilla, P. Bernard, V. Gotor \& H. Fernández. 2006b. Gibberellins and antheridiogen on sex in Blechnum spicant L. Plant Cell Rep. 25: 1104-1110.

Mickel, J. T. \& J. M. Beitel. 1988. Pteridophyte flora of Oaxaca, Mexico. Mem. New York Bot. Gard. 46: 1-568.

Mickel, J. T. \& A. R. Smith. 2004. The pteridophytes of Mexico. Mem. New York Bot. Gard. 88: $1-1054$. 
Moran, R. C. 1995. Blechnaceae. In: Moran R. C. \& R. Riba (eds.). Flora Mesoamericana Vol. I. Psilotaceae a Salviniaceae. Instituto de Biología, Universidad Nacional Autónoma de México, Missouri Botanical Garden and The Natural History Museum (London). pp. 325-332.

Nayar, B. K. 1962. The gametophyte of some species of Blechnum. J. Indian Bot. Soc. 41: 33-44.

Nayar, B. K., N. Bajpai \& F. Raza. 1966. Morphological studies on some species of Blechnum, Doodia, Woodwardia and Stenochlaena-I: The gametophytes and juvenile sporophytes. J. Linn. Soc. Bot. 59: 405-423.

Nayar, B. K. \& S. Kaur. 1969. Types of prothallial development in homosporous ferns. Phytomorphology 19: 179-188.

Nayar, B. K. \& S. Kaur. 1971. Gametophytes of homosporous ferns. Bot. Rev. 37: 295-396.

Pérez-García, B., A. Mendoza \& M. Ricci. 1996. Morfogénesis de la fase sexual de Blechnum chilense y Blechnum cycadifolium (Blechnaceae). Rev. Biol. Trop. 44: 491-497.

Rodríguez-Ríos, R. 1973. Morfología de los protalos y esporofitos jóvenes de algunas especies chilenas de Blechnum (Polypodiaceae s.l.). Gayana, Bot. 22: 1-30.

Smith, A. R. 1981. Pteridophytes. In: Breedlove, D. E. (ed.). Flora of Chiapas. Vol. 2. California Academy of Sciences. San Francisco. 370 pp.

Stokey, A. G. 1951. The contribution by the gametophyte to the classification of the homosporous ferns. Phytomorphology 1: 39-58.

Stokey, A. G. \& L. Atkinson. 1952a. The gametophyte of Stenochlaena palustris (Burm.) Bedd. Phytomorphology 2: 1-9.

Stokey, A. G. \& L. Atkinson. 1952b. The gametophyte of Blechnum spicant (L.) Wither and B. buchtienii Rosenst. Phytomorphology 2: 9-15.

Stone, I. 1961. The gametophytes of the victorian Blechnaceae I. Blechnum nudum (Labill.) Luerss. Austral. J. Bot. 9: 120-136.

Stübner, G. A. 1882. Beitrag zur Entwicklungsgeschichte des Vorkeims der Polypodiaceen. 13 Berichte über die Königliche Realschule I. Ordnung und Landwirtschaftsschule zu Döbeln. 19 pp.

Tryon, R. M. \& A. F. Tryon. 1982. Ferns and allied plants, with special reference to tropical America. Springer-Verlag. New York. 857 pp. 